\title{
The Adoption of Automatic Teller Machines in Nigeria: An Application of the Theory of Diffusion of Innovation
}

\author{
Wole Michael Olatokun \\ Department of Library and \\ Information Studies, \\ University of Botswana, \\ Gaborone, Botswane
}

wole.olatokun@mopipi.ub.bw

\author{
Louisa Joyce Igbinedion \\ Africa Regional Centre for \\ Information Science, \\ University of lbadan, Nigeria
}

\begin{abstract}
This study tested the attributes of the theory of diffusion of innovation empirically, using Automatic Teller Machines (ATMs) as the target innovation. The study was situated in Jos, Plateau state, Nigeria. The population comprised banks customers in Jos who used ATMs. The sampling frame technique was applied, and 14 banks that had deployed ATMs were selected. Cluster sampling was employed to select respondents for the study. Data collection instrument was a structured questionnaire administered to 600 respondents of which 428 were returned giving $71.3 \%$ return rate. Principal Factor Analysis, and Multiple Regression were the analytical techniques used. The demographic characteristics of the respondents revealed that most of them were students and youths. From the factor analysis, it was revealed that the respondents believed in the ir safety in using ATM; that ATMs were quite easy to use and fit in with their way of life; that what they observed about ATMs convinced them to use it and that ATM was tried out before they use it. The constructs Relative Advantage, Complexity, Compatibility, and Trialability were all found to have a significant impact on the Attitude towards ATM, which in turn had a significant impact on the Intention to use it. Relative Advantage and Compatibility had almost the same weight of impact on Attitude; while Observability had the highest impact on attitude. To increase the diffusion of ATMs, it was recommended that banks should ensure enhanced salience of ATM to customers' needs, greater compatibility of ATM to customers banking norms and lifestyle, less complex and easy to use system and opportunity for adopters to experiment with the system before using ATMs.
\end{abstract}

Keywords: Adoption, Automatic Teller Machine (ATM), Banks, Diffusion of Innovation, Nigeria

Material published as part of this publication, either on-line or in print, is copy righted by the Informing Science Institute. Permission to make digital or paper copy of part or all of these works for personal or classroom use is granted without fee provided that the copies are not made or distributed for profit or commercial advantage AND that copies 1) bear this notice in full and 2) give the full citation on the first page. It is permissible to abstract these works so long as cred it is given. To copy in all other cases or to republish or to post on a server or to redistribute to lists requires specific permission and payment of a fee. Contact Publisher@InformingScience.org to request redistribution permission.

\section{Introduction}

Globally, Automatic Teller Machines (ATMs) have been adopted and are still being adopted by banks. They offer considerable benefits to both banks and their depositors. The machines can enable depositors to withdraw cash at more convenient times and places than during banking hours at branches. In 
addition, by automating services that were previous ly completed manually, ATMs reduce the costs of servicing some depositor demands. These potential benefits are multiplied when banks share their ATMs, allowing depositors of other banks to access their accounts through a bank's ATM (McAndrews, 2003). Banks have become the principal deployers of ATMs. Two reasons for this are that they want to increase their market share, although due to the prevalence of ATMs, it is not likely to be the primary means by which ATMs increase profitability for most banks; or/and above a certain level of operations, the cost of a single transaction performed at an ATM is potentially less than the cost of a transaction conducted from a teller, as ATMs are capable of handling more transactions per unit of time than are tellers (Laderman, 1990).

In Nigeria the deployment of ATM by banks and its use by bank customers is just gaining ground and has burgeoned in recent times. This has happened especially after the recent consolidation of banks, which has in all probability, made it possible for more banks to afford to deploy ATMs or at least become part of shared networks (Fasan, 2007). The increased deployment of ATMs in the banking sector has made the issue of technology relevance important. ATM services have a history that is less than ten years in Nigeria. At first, they were operated as elitist services designed for those desirous of exclusive service. Cards were rare and the process for obtaining them tortuous. Presently, the use of ATM cards has been widely promoted. Banks no longer appear to want personal contact with their customers. Some banks have resorted to penalizing the customer as it were, for not possessing an ATM card, by debiting the account of such a customer for withdrawing below a certain amount across the counter. Agboola (2006) reported that although only a bank had an ATM in 1998, by 2004, fourteen of them had acquired the technology. Agboola (2006) discovered that the adoption of ICT in banks has produced largely positive outcomes such as improved customer services, more accurate records, ensuring convenience in business time, prompt and fair attention, and faster services etc. Also, the banks' image is improved creating a more competent market. Work has also been made easier, and more interesting, the competitive edge of banks, relationship with customers, and the solution of basic operational and planning problems has been improved. Fanawopo (2006) stated that Nigeria's debit card transactions rose by 93 per cent between January 2005 and March 2006 over previous years owing to aggressive roll out initiatives by Nigerian banks, powered by Interswitch network. The number of ATM transactions through the Interswitch network had increased from, 1,065,972 in 2004, to 14, 448, 615 between January 2005 to March 2006. This is a rise of 92.6 percent with respect to the previous years. More than 800 ATMs have been deployed on the network, while about 2 million cards have been issued by 23 banks as at March 2006.

A recent survey conducted by Intermarc Consulting Limited revealed that ATM services provided by banks and non-financial institutions stood as the most popular e-business platform in Nigeria (Intermarc Consulting Limited, 2007). The report showed that awareness for various banking services rendered by Nigerian banks is mostly limited to the traditional banking services. Findings showed that 99 percent of the respondents were aware of savings accounts, while 92 percent were aware of current accounts and 72 percent are aware of local money transfer services. However, among the more modern banking services such as electronic banking, Internet banking, Point of Sales $(\mathrm{PoS})$ transactions, money transfer, ATMs emerged as the most popular with 96 percent awareness level. ATM awareness also ranked higher than awareness level about current accounts and slightly below savings account (Omankhanlen, 2007). In order to encourage customers to embrace the technology and overcome their fears of putting the ir checks into a machine's slot rather than a teller's hand, banks originally did not charge customers any fees for using ATMs. In time, some banks started charging customers for not using ATMs, through so-called "human teller fees"- a charge for each time a customer uses a teller for a service that could be performed by an ATM. Banks that embraced the ATM profited handsomely, often growing far faster. At first, a bank's ATMs could only be used by customers who already had current or savings accounts with that bank, through the bank's proprietary ATM network (Ugwu, 2008). 
According to Merton (1992), the primary function of a financial system is to facilitate the allocation and deployment of economic resources, both spatially and across time, in an uncertain environment. This conception would also apply to financial innovations such as ATMs and highlights the view that a financial innovation represents something new that reduces costs, reduces risks, or provides an improved product/service/instrument that better satisfies participants' demands (Frame \& White, 2002). This burgeoning of ATMs in Nigeria calls for a study on its diffusion that would give insight into issues such as, how far it might go; if it is being adequately adopted by users; if it is necessary at all; and what could be done, if need be, to improve on its use in the country. Frame and White (2002) emphasized the need for studies on financial innovation to aid research and assist financial regulators, since hypotheses advanced by the broad descriptive literature on innovation remain largely untested. Reportedly, a lot of the testing of hypotheses involving innovation has come from individuals trained in the economic aspect of industrial organization. The data and research environments have not been conducive to empirical work on financial innovation (Frame \& White, 2002).

In Nigeria, it appears that both reasons are valid because the banks with more ATMs appear to be more current, visible and likely to deliver better services on time, which might influence an adopter's decision to use an ATM; besides this, the stiff competition among banks trying to carve niches in the stock market, alongs ide the large size of potential customer patronage (as a result of the large population of the country) makes ATM adoption for banks crucial. At present in Nigeria, there is a fostering of shared networks. Shared networks are used probably because they increase the convenience of ATM use by enabling a given bank's customers to carry out banking transactions over a wider geographic area than would be poss ible with a proprietary network. Also, it is not necessary for a bank to own an ATM in order to belong to a shared network. Through spreading the fixed cost associated with ATMs over transactions initiated by customers of many different banks, a shared network can take advantage of economies of scale (Laderman, 1990).

Hence, there is clearly a need to study the issue of adoption of ATM Nigerian context, especially from the perspective of information science. This is because the diffusion of the innovation of automatic teller machines can be specifically perceived through the attitudes and actions of users. The Diffusion of Innovation Theory (DOI), used in this study, attempted to examine the factors that influenced an individual to adopt an innovation. The theory proposed five focal beliefs or constructs that influence the adoption of any innovation. These are relative advantage, complexity, compatibility, tria lability, and observability. Relative advantage indicates the usefulness of an innovation; compatibility is the degree to which an innovation is perceived as consistent with existing values, past experiences, and the needs of the potential adopter; complexity is the degree to which an innovation is perceived as relatively difficult to understand and use; trialability is trying out or testing an innovation so that it makes meaning to the adopter; and observability is the degree to which the results of an innovation are visible to others (Rogers, 1995). The essence of the use of these constructs is to empirically test part of DOI's attributes with a view to exploring factors that brought about the adoption of the innovation (automatic teller machines). An innovation in this study is taken to mean an idea, practice, or object that is perceived to be new by a person or adopting entity.

\section{Rationale}

In Nigeria, Automatic Teller Machine technology is becoming more common than it ever was. ATMs appear to be mainly provided by banks in Nigeria (Fasan, 2007). Yet, their widespread adoption by customers of banks is not clear, as it appears that peoples' perception of the technology is diverse, which in turn affects their decision to actually use ATMs or not. ATMs are set up to provide 24 hour services to bank customers, who cannot expect to be able to transact with 
banks in the same period of time (Ugwu, 2008). Nevertheless, it is observed that banks still have many customers transacting with tellers within the ir doors, and queues are still not a thing of the past inside banks. The patronage of ATMs is also not well defined, and even epileptic at best, as sometimes long queues were observed outside ATMs, while at other times, there are few or no customers. It is consequently, important to discover why this is so, because as a technology, ATMs are supposed to make life easier and more efficient for the customers of banks. Concerning banks, ATMs ought to assist in improving a banks' turnover (Batiz-Lazo \& Barrie, 2005). Therefore, low patronage of ATMs by their customers could affect the banks' profit adversely.

Therefore, there is a need to study the constructs that could affect the adoption of Automatic Teller Machines. Using a popular and widely used theory such as the theory of diffusion of innovation, it is expected from this study that the extent of diffusion of ATM will be determinable with a view to knowing what could be done to prevent the inhibition surrounding its use. Thus, it could be reasoned that the benefits of ATM can only accrue to adopters in Nigeria when barriers to their diffusion and adoption are identified. The DOI theory was used in an attempt to model the use of ATM in Nigeria, so that the progression of its use could be anticipated and fully catered for by banks. Although the application of the theory had been tested in previous studies there is a need for it to be applied locally using a recently introduced technology, such as ATM in Nigeria. The use of the theory is vital as there is a requirement for more information that could add to existing research. Furthermore, there appears to be a dearth of information concerning diffusion studies on ATM in Nigeria using the DOI model. Accordingly, this could reveal areas that require further research, and provide answers to hitherto obscure questions concerning ATM adoption and diffusion.

\section{Previous Studies}

A number of researchers have investigated the demographic characteristics of ATM adopters. ElHaddan and Almahmeed (1992) studied a Kuwaiti population, Marshall and Heslop (1988) studied a Canadian population, and Swinyard and Ghee (1987) studied a Southeast Asian population and all got cons istent results of adopter characteristics of ATM, in which ATM users tend to be young and have above average incomes and at least some high school education. Taube (1988) and Amel (1986) in the ir studies also obtained similar results. Kennickell and Kwast (1997) specifically found that household heads under the age of 35 were considerably more likely to use computerized banking, ATMs, and debit cards than older consumers, while consumers' use of direct deposit increased with age. Rugimbana's (1995) study profiled users and non-users of ATMs in terms of demographic and perceptual variables. The main aim of the study was to discriminate users from non-users, using the demographic variables of respondents and their perceptions of ATM attributes in order to assess the relative importance of these predictor variables. It was found that perceptual variables were far more successful as predictors of ATM service usage than respondent demographic variables. Darch and Caltabiano (2004) explored the relationship between demographic, user-situational, attitudinal variables and ATM use in an Australian sample of older adults. These adults were Volunteers aged 60 years and above, who conducted their own banking transactions. Technology, perceived control and perceived user comfort were found to have an independent signif icant effect on ATM usage. Age, education, attitudes and usersituational variables were found to be related to ATM use, only technology experience, perceived user comfort and control were found to be determinants of ATM use.

Di Angeli et al. (2002) looked at technology adoption in different cultural contexts, analyzing the relationship between Hoffstede's cultural value dimensions and ATM's adoption in urban India. They proposed that the underlying inhibitors to ATM adoption in India were not intrinsically different from those determined earlier in Europe and North and South America. These inhibitors could be traced back to a few main factors, such as feelings of inadequacy, preference for human 
contact, lack of need and safety concerns. They believed that those who used ATM did so because they had a need for it, perceived it was easy to use, felt safe using it, and had pos itive attitude towards technology in general. These reasons appeared to be caused by different factors in different contexts due to different cultural values. For India, Di Angeli et al. (2002) stated that the feeling of inadequacy was the result of a strong value dimension expecting different access to resources as a function of people's social status. The long-term orientation of Indians explained why they did not mind queuing to access basic financial services. Lee and Lee (2000) investigated the diffusion of various electronic banking technologies, such as ATMs, debit cards, smart cards, direct deposit, and direct payment, along with the characteristics of adopters and nonadopters based on the DOI theory. They used the 1995 Survey of Consumer Finances and discovered that more educated, affluent and younger consumers who were likely to communicate with professional information providers tended to adopt electronic banking technologies more readily than their counterparts. Despite this, the specific factors that described adopters and non-adopters varied across different types of banking technologies.

Rogers et al. (1996) stressed that the most technologically savvy bank customers sometimes had trouble comprehending the maze of options available. A lot of people keep trying until they find solutions, but the elderly usually have problems using ATMs. Banks may be losing the elderly as ATM customers. Education and machine redesign could be the best hope for elderly customers. Most systems designers and bank officers assumed that ATM was easy to use and required no training. Evidence however showed that users of all ages had problems using ATMs initially when no training is provided, and that older adults have problems even after training. They indicated that banks could find better ways of teaching people how to use ATMs. Out of the 13 banks they randomly questioned, only two provided brochures that showed the user how to operate the ATM, and these brochures were perfunctory at best. In their study, non-users of ATMs did not use the machines as they did not see a need for the service, probably explained by the ir lack of know ledge about how the system worked and their discomfort in having to learn it while others waited. Many respondents were not aware of the different options offered on ATM and were more predisposed to use it if they were provided training. Non-users and users stressed concerns about safety in using ATMs.

Hone et al. (1998) found that in spite of the success and widespread use of ATMs, a significant proportion of bank customers could not or would not use them, or experience difficulties in the ir interactions. They suggested that speech technology should be used as a means by which nonusers might be encouraged to use ATMs, while at the same time, improving usability for all. The advantages of this include hands-free and eyes-free use for physically- and visually impaired users, and improved ease and speed of use through increased naturalness of the interaction. Hone et al. (1998) investigated user attitudes to the concepts of a speech-based ATM, via large-scale survey and a series of focus groups. They detected that the idea of using speech for ATM transactions led to concerns such as that of privacy and security. Visually impaired users were more likely to want speech technology which meant that enhancements to ATM did not necessarily suit all types of users.

Through archival research, Batiz-Lazo and Barrie (2005) investigated the impact of the introduction of Automated Teller Machines (ATM) in British retail banking. ATMs were originally a British innovation but U.S. (e.g., IBM and NCR) and German manufacturers (e.g., Siemens) took the lead as ATMs became a global technology. The evolution of ATM showed how banks adopted on-line, real-time computing for the entire branch network and highlights the role of network externalities in financial markets. From a business history perspective, ATM characterized a shift in bank strategy, namely how applications of computer technology moved from be ing potential sources of competitive advantage to being a minimum requirement for effective competition in retail finance. Batiz-Lazo and Barries's study argued that during the 1990s, Information 
Technology in banking (as measured by ATM) led to reduced operating costs, coupled with increased output (number of transactions) that resulted in greater efficiency. They concluded that the introduction of ATM was profitable for banks as well as customers. Their study indicated that banks' adoption of ATM was overall beneficial for banks.

A survey conducted by Intermarc Consulting Limited revealed that ATM services provided by banks and non-financial institutions stood as the most popular e-business platform in Nigeria. The report showed that awareness for various banking services rendered by Nigerian banks was mostly limited to the traditional banking services (Intermarc Consulting Limited, 2007). Findings equally showed that 99 percent of the respondents were aware of savings accounts, 92 percent were aware of current accounts while 72 percent were aware of local money transfer services. However, among the more modern banking services such as electronic banking, Internet banking, PoS transactions, money transfer, etc ATM emerged as the most popular with 96 percent level of awareness. Awareness level of ATM also ranked higher than that of current accounts and slightly below savings account. In addition, the report indicated that Inter-bank transactions dropped by 30.2 percent in October 2006 to 29.8 percent in October 2007, implying strong adoption of ATM. Cardholders were also aware that they could use devices deployed by other banks as well as other channels.

\section{Research Model}

The theory of diffusion of innovation postulated that five attributes of an innovation influence its adoption (Rogers, 1995). These attributes have concepts in common with adoption research and diffusion studies, being used to assess a variety of communications and information technology. Spheres such as engineering, medicine, information systems, banking etc have been used to justify the DOI theory (Rogers, 1995; Tornatzky, \& Fle ischer, 1990). Mostly, the theory had been used in IT related technologies - software (Morris \& Dillon, 1997), operating systems (Karahanna, Staub, \& Chervany, 1999), Intranet Use (Horton et al., 2001), smart card readers (Plouffe et al., 2001), information systems processes (Mustonen-Ollilial \& Lyytinen, 2003) and Internet banking (Gerrard \& Cunningham, 2003; Kolodinsky et al, 2004; Tan \& Teo, 2000). Moore and Benbasat (1991) used the DOI's attributes to develop an instrument that can be used to measure the perceptions of adopting an information technology. In this instrument Moore and Benbasat kept four of Roger's innovation characteristics namely relative advantage, compatibility, ease of use (complexity), and Tria lability. They added additional constructs voluntariness and image and split Observability into two separate constructs, result demonstrability and visibility. The result was a valid and reliable 38 - item instrument made up of eight unique scales. DOI attributes were used to predict computing resource center usage in a study by Taylor and Todd (1995). They used three DOI attributes, relative advantage, complexity and compatibility, as part of their research model to predict the attitude towards using the center. The results showed that these attributes explained about $76 \%$ of the variance in attitude and in terms of hypothesized paths, only perceived usefulness signif icantly affected attitude. Parthasarathy and Bhattacherjee (1998) used DOI to examine the post-adoption behavior among users of online services. In this study, they postulated that there were distinct factors that discriminate between continuers and discontinuers of an innovation. Factors that were analyzed included communication influence, utilization level, relative advantage, complexity, compatibility, and network externalities. The study found that all factors were significant discriminators except utilization (weakly supported) and ease of use. Specifically on the DOI attributes, their results indicated that discontinuers perceived the service as less useful and less compatible with their work habits.

Karahanna et al. (1999) combined DOI and TRA (theory of reasoned action) to examine factors that influenced Windows 3.1 adoption across time. Based on Moore and Benbasat's (1991) instrument, seven attributes were tested: perceived usefulness (relative advantage), image, compati- 
bility, ease of use, visibility, result demonstrability, and tria lability. The result of the study was that among the potential adopters, all of the attributes except image significantly affected the adoption attitude. For users, only perceived usefulness an image was found significant. Tan and Teo (2000) utilized four DOI attributes, relative advantage, compatibility, complexity, and trialability, as part of their research model to predict the intention to adopt Internet banking services. They found that relative advantage, compatibility, and trialability significantly affected the intention to use Internet banking, whereas complexity was not significant. Plouffe, Hulland, and Vandenbosch (2001) compared the DOI with the technology acceptance model (TAM) in predicting the adoption intention of smart card readers among retailers. Seven attributes were tested in this study. The study found that relative advantage, compatibility, image, visibility, and tria lability signif icantly explained the intention to adopt the technology. In terms of comparison between the two models, the study found that DOI and TAM explained $45 \%$ and $36.2 \%$ of the variance in intention to adopt, respectively.

DOI was also used in a study of online consumer's intention to use virtual stores (Chen, Gillenson, \& Sherrell, 2002). The study was conducted on 253 registered users of a non-profit organization and three news groups. In this study, a DOI attribute, compatibility was added to TAM. They found that compatibility between using a virtual store and a consumer's belief; values and needs positively affected one's attitude towards using the virtual stores. Lau (2002) utilized the DOI's attributes to predict broker's adoption of online trading in Hong Kong. The study found that perceived usefulness, perceived ease of use or complexity, relative advantage, compatibility, and observability were signif icantly correlated with the attitude of using the system. Hardgrave, Davis, and Riemenschneider (2003) used TAM and DOI attributes to conduct a study to identify the factors that influenced application developers' intention to follow a software development methodology. Relative advantage, complexity, and compatibility were used as part of the research model. The results showed that usefulness and compatibility significantly influenced the intention. Complexity was not significant.

Gerrard and Cunningham (2003) used DOI in a study of Internet banking diffusion in Singapore. They found that adopters of Internet banking perceived the service as more convenient, less complex and more compatible to them. In a review on the technology acceptance models, Venkatesh, Morris, Davis, and Davis (2003) found that relative advantage, complexity, result demonstrability, trialability, visibility, image, compatibility, and voluntariness all explained approximately $54 \%$ and $47 \%$ of the variance in intention in voluntary and mandatory settings. Concerning hypothesized paths, two DOI attributes, relative advantage and complexity were significant in predicting intention both in voluntary and mandatory settings. Image was a significant predictor of the intention only in mandatory settings.

In this study, the five attributes for innovation according to Rogers (1995) - relative advantage, compatibility, complexity, trialability and observability would be tested to find out the degree to which they influence attitude and thus intention to use the technology. The constructs are defined as follows:

Relative Advantage: This expresses to what degree the new product is better than the one it replaces. Relative advantage could be judged not only by profit, but by factors such as the ease of use and storage etc.

Compatibility: This relates to how the production of the innovation and the innovation itself takes into account the local values and customs of the adopters. It is the point at which an innovation fits into the specific society. The smoother the innovation fits into the culture, the faster the rate of adoption. 
Complexity: This is the extent of how complex it is for an adopter to understand and use an innovation. Logically, the harder an innovation is to use, or perceived to use, the less likely that an adopter would be able to consume it.

Trialability: This is the capacity of the consumer to give the innovation a try or test before deciding to adopt it or not. This enables the rate of adoption to increase after a successful trial.

Observability: This property is the idea that when an innovation benefit does not instantly solve a consumer's problem or need, it will not diffuse through a society as quickly compared to an innovation that is more of a solution to a problem. It is also the degree to which the results of an innovation are visible to others. What is observed is what can be communicated, and this could affect diffusion depending on the outcome of what has been observed.

The Attitude construct received its first serious attention from Darwin in 1872. Darwin defined attitude as a motor concept, or the physical expression of an emotion (Ndubisi \& Sinti, 2006). Fishbein and Ajzen (1975) argued that attitude towards behaviour is made up of beliefs about engaging in the behaviour and the associated evaluation of the belief. According to them, attitude is defined as an individual's positive and negative feelings (evaluative affect) about performing the target behaviour. Attitude toward behaviour refers to the degree to which a person has a favourable or unfavourable evaluation or appraisal of the behaviour in question. Taylor and Todd (1995) suggested that the different dimensions of attitudinal belief toward an innovation could be measured using the five perceived attributes (relative advantage, compatibility, complexity, trialability and observability) of the innovation.

Figure 1 presents the research model.

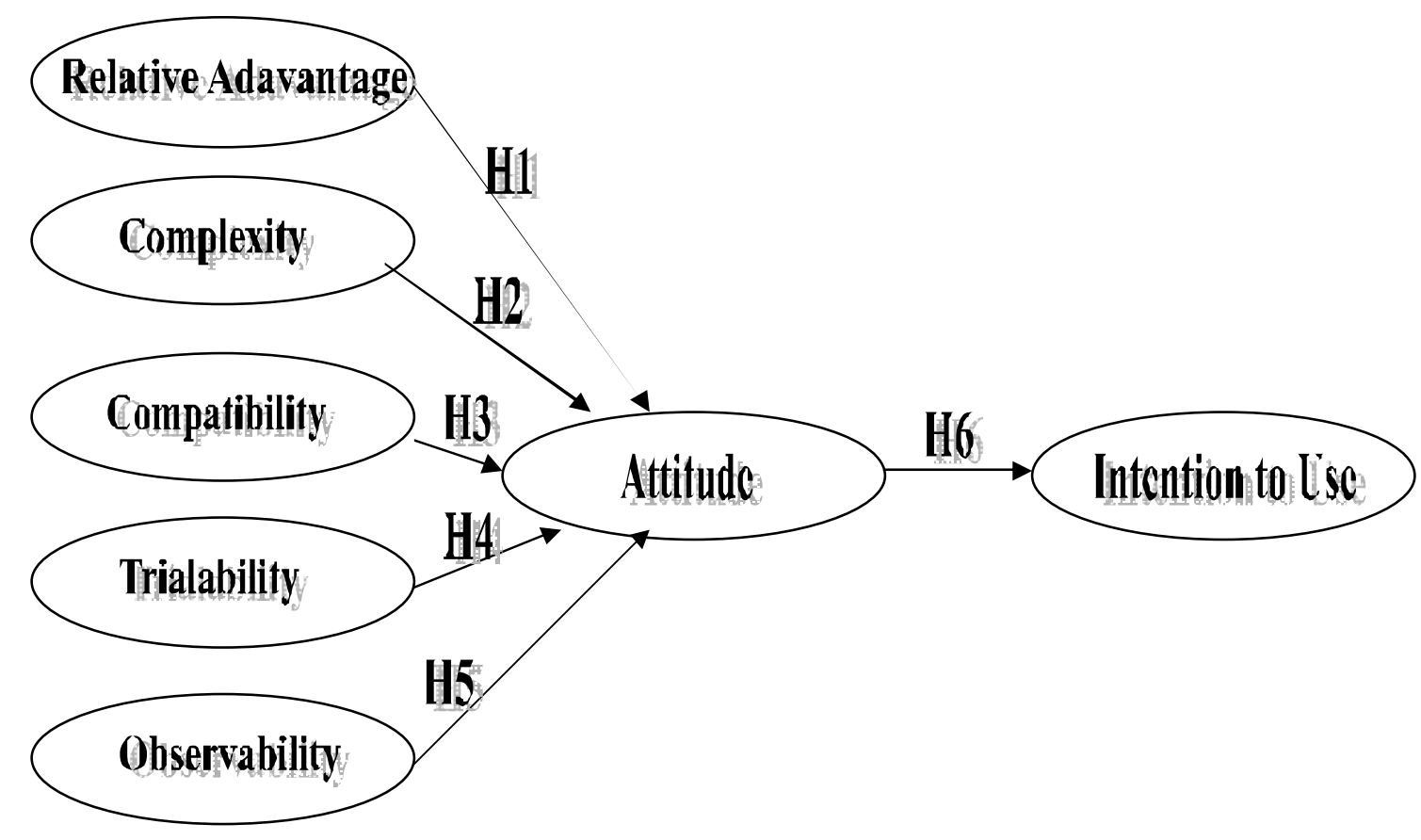

Figure 1: The Research Model

The research model adopted in this study depicts what should occur given the constructs that have been put forward by Rogers (1995) concerning the adoption of a technology. These constructs ought to affect the intention to use a particular innovation which in this case is ATM. Thus, the model indicates that the five constructs: relative advantage, complexity, compatibility, trialability and observability of using ATM would affect the attitude of the adopter which in turn will affect 
the intention of the adopter to use an ATM. Thus, all the constructs are collectively likely to have an effect on the adopter's attitude towards ATM which would invariably affect the adopter's intention to use it. Intention to use an ATM has direct bearing on whether the machine is actually used or not.

From the model, the following were the hypothesis proposed for this study:

Hypothesis 1: The relative advantage of using Automatic Teller Machines does not positively affect the attitude towards using the technology.

Hypothesis 2: The complexity of the use of Automatic Teller Machines does not positive ly affect the attitude towards using the technology.

Hypothesis 3: The compatibility of Automatic Teller Machines with the adopter's values does not positively affect the attitude towards using the technology.

Hypothesis 4: The trialability of Automatic Teller Machines does not positively affect the attitude toward using the technology.

Hypothesis 5: The observability of Automatic Teller Machines does not positively affect the attitude towards using the technology.

Hypothesis 6: The attitude towards Automatic Teller Machines does not positively affect the intention to use the technology.

\section{Design, Data Collection and Analysis}

The research method used was the social survey. The location of the study was Jos, a Nigerian metropolis. Jos was chosen as the area for this study because as a middle belt region of the country, it lies almost between the two halves of the country. As it is a melting pot of the different people of Nigeria, apart from its own indigenes, it was anticipated to obtain broader and varied views of opinions. The study population comprised the customers of banks in Jos metropolis who used ATMs. These customers came from different backgrounds and were of different ages with other individual differences. A fairly representative sample was obtained by employing the use of a sampling frame and technique. When this research was conducted, there were 25 banks in Nigeria. Out of these, 21 were found to be present in Jos. From these 21 banks, 7 had not deployed ATMs (although some of them claimed to issue ATM cards with which their customers could use other ATMs). This left a total of 14 banks that had deployed ATMs. These 14 banks constituted the units from which ATM users were selected. Cluster sampling was adopted. This involved the division of the population into clusters or groups and drawing samples from the clusters. A cluster in this study was represented by the number of customers who patronized a particular bank. This cluster unit was considered likely to be heterogeneous because the members of each cluster were from different backgrounds, of different ages, economic classes, occupations etc. The members of each of the clusters had the common characteristic of ATM use. Since there were 14 banks that had deployed ATMs, the number of clusters used was 14, with each cluster containing the customers using the ATM of a particular bank.

The data collection instrument used was a structured questionnaire because questionnaires are extremely flexible and could be used to gather information concerning almost any topic, from a large or small number of people (Moore, 1987). It was adopted for adequately testing the hypotheses to establish the continuous relevance of a theory (Osiki, 2006). The 21-item questionnaire was divided into 7 sections. Section A consisted of closed-ended questions covering the demographic characteristics of the respondent. Section B aimed at collecting data on the relative advantage of using ATMs. Section C aimed at finding out whether any complications had been encountered since using ATMs. Section D was to elic it information on the suitability of using 
ATM with the belief system, moral and ethical values of the respondent. Section E was about the possible trials that the respondent had embarked upon before finally accepting the use of ATM while Section F was to obtain information about the observed benefits of using ATM. Section G was included to acquire information on how the experiences of the respondent with the use of ATMs have affected the intention to continue to use the technology. A 5-point Likert scale was used in designing the questions.

Six-hundred copies of the questionnaire were administered to ATM customers of the selected 14 banks. Forty copies were administered to each cluster of customers of a particular bank. A total of 428 useable copies of the questionnaire were returned. The percentage of the useable copies of the questionnaire was 71.3 percent. Cronbach's coefficient alpha was used to determine the internal consistency and reliability of the multiple item scales. Cronbach's alpha was used in this study because every item was measuring an underlying construct (Leech, Barrett, \& Morgan, 2005).

Table 1: Re liability Test

\begin{tabular}{lll}
\hline Construct & $\begin{array}{l}\text { Cronbach's } \\
\text { Alpha }\end{array}$ & $\begin{array}{l}\text { No. of Items that } \\
\text { Make up Construct }\end{array}$ \\
\hline Relative Advantage & 0.79 & 10 \\
Complexity & 0.87 & 14 \\
Compatibility & 0.84 & 15 \\
Observability & 0.82 & 7 \\
Trialability & 0.75 & 5 \\
\hline
\end{tabular}

Table 1 showed the Cronbach's alpha that was computed for the items that made up each construct used in this study. The alpha values for the 5 constructs indicated that the items that formed them had reasonable internal consistency reliability - being from 0.75 and 0.87 . The items which were deleted had alpha values that were either lesser than 0.3 or higher than 0.9 . Items lower than 0.3 might affect the consistency of the results of further analysis. Items with alpha values over 0.9 were probably repetitious or added up to be more than was required for the construct. As such, removing such items helped in getting better results in further analys is (Leech, Barrett, \& Morgan, 2005).

The scores used for the constructs in this study were standardized using Excel software before being imported into SPSS for the regression analysis. Principal Factor Analysis and Multiple Regression were used to analyze the data, using SPSS (the Statistical Package for Social Sciences). The hypothesis results were then obtained based on the final structural model. Miss ing data analys is resulted in 27 cases being dropped out of the 428 cases available for analysis. The final count of cases was 401. As shown in Table 2, there were more males than females at $63 \%$ to $36.2 \%$. Majority of the respondents were between the ages of 20-29 years. This result supports the findings of a lot of studies on ATM, where users tended to be young and had at least secondary school level education (Amel, 1986; El-Haddan \& Almahmeed, 1992; Marshal \& Heslop, 1988; Swinyard \& Ghee, 1987; Taube, 1988). 
Table 2: Demographic Profile $(n=401)$

\begin{tabular}{|c|c|c|c|}
\hline Variable & Category & Frequency & Percent \\
\hline \multirow[t]{2}{*}{ Gender } & Male & 256 & 63.8 \\
\hline & Female & 145 & 36.2 \\
\hline \multirow[t]{6}{*}{ Age } & Under 20 & 21 & 5.2 \\
\hline & $20-29$ & 177 & 44.1 \\
\hline & $30-39$ & 113 & 27.9 \\
\hline & $40-49$ & 59 & 14.7 \\
\hline & $50-59$ & 24 & 6.0 \\
\hline & Over 59 & 8 & 2.0 \\
\hline \multirow[t]{6}{*}{ Occupation } & Student & 129 & 32.2 \\
\hline & Civil Servant & 88 & 21.9 \\
\hline & Self Employed & 71 & 17.7 \\
\hline & Academic & 39 & 9.7 \\
\hline & Technician & 24 & 6.0 \\
\hline & Professional & 50 & 12.5 \\
\hline \multirow[t]{6}{*}{ Education } & Primary/Second ary & 25 & 6.2 \\
\hline & OND/NCE & 43 & 10.7 \\
\hline & HND & 46 & 11.5 \\
\hline & BSc/B.A/B.Ed. degree & 246 & 61.3 \\
\hline & MSc/M.A.M.Ed. degree & 36 & 9.0 \\
\hline & $\mathrm{PhD}$ & 5 & 1.2 \\
\hline \multirow[t]{4}{*}{ Religion } & Christianity & 365 & 91.0 \\
\hline & Islam & 27 & 6.7 \\
\hline & Traditional Religion & 2 & 0.5 \\
\hline & Other & 7 & 1.7 \\
\hline
\end{tabular}

Note: $O N D=$ Ordinary National Diploma; NCE=National Certificate of Education; HND=Higher National Diploma; $B S c .=$ Bachelor of Science; B.A.=Bachelor of Arts; B.Ed.=Bachelor of Education; MSc. $=$ Master of Science; M.A. $=$ Master of Arts; M.Ed.=Master of Education; PhD=Doctor of Philosophy

\section{Results}

Tables 3, 4, and 5 present the results from the multiple regression carried out using the five constructs: Relative Advantage; Complexity; Compatibility; Observability and Trialability as the independent variables and Attitude as the dependent variable. This was done to determine the best linear combination of the constructs for predicting Attitude. 
Table 3: Model Summary for the constructs

\begin{tabular}{l|llll}
\hline Model & $\mathbf{R}$ & R Square & Adjusted R S quare & $\begin{array}{l}\text { Std. Error of the } \\
\text { Estimate }\end{array}$ \\
\hline 1 & $.806(\mathrm{a})$ & .649 & .644 & .382 \\
\hline
\end{tabular}

Predictors: (Constant), Observability, Trialability, Relative Advantage, Complexity, Compatibility Dependent Variable: Attitude

Table 4: ANOVA for the constructs

\begin{tabular}{l|lllllll}
\hline \multirow{2}{*}{ Model } & & $\begin{array}{l}\text { Sum } \\
\text { Squares }\end{array}$ & of & Df & $\begin{array}{l}\text { Mean } \\
\text { Square }\end{array}$ & F & Sig. \\
\hline 1 & & Regression & 106.720 & 5 & 21.344 & 146.004 & $.000(\mathrm{a})$ \\
& Residual & 57.744 & 395 & .146 & & \\
& Total & 164.464 & 400 & & & \\
\hline
\end{tabular}

Predictors: (Constant), Observability, Trialability, Relative Advantage, Complexity, Compatibility Dependent Variable: Attitude

Table 5: Coefficients of the constructs

\begin{tabular}{|c|c|c|c|c|c|c|c|c|}
\hline \multicolumn{2}{|c|}{ Model } & \multicolumn{2}{|c|}{$\begin{array}{l}\text { Unstandardized } \\
\text { Coefficients }\end{array}$} & \multicolumn{3}{|c|}{$\begin{array}{l}\text { Standardized } \\
\text { Coefficients }\end{array}$} & \multicolumn{2}{|c|}{$\begin{array}{l}\text { Collinearity } \\
\text { Statistics }\end{array}$} \\
\hline 1 & & $\mathbf{B}$ & $\begin{array}{l}\text { Std. } \\
\text { Error }\end{array}$ & Beta & $\bar{t}$ & Sig. & $\begin{array}{l}\text { Toler- } \\
\text { ance }\end{array}$ & VIF \\
\hline & (Constant) & .111 & .144 & & .771 & .441 & & \\
\hline & RelAdv & .252 & .046 & .231 & 5.484 & .000 & .502 & 1.991 \\
\hline & Complx & .152 & .037 & .164 & 4.114 & .000 & .557 & 1.795 \\
\hline & Compati & .231 & .040 & .232 & 5.737 & .000 & .543 & 1.842 \\
\hline & Trial & .077 & .030 & .090 & 2.610 & .009 & .744 & 1.345 \\
\hline & Observ & .294 & .035 & .318 & 8.366 & .000 & .614 & 1.628 \\
\hline
\end{tabular}

From Table 3, it can be seen that the R Square value for the model showed that $64.4 \%$ of the variance in the model can be predicted from the independent variables. Table 4 presents the ANOVA report on the general significance of the model. As $\mathrm{p}$ is less than 0.05 , the model is significant. Thus, the combination of the variables significantly predicts the dependent variable $(\mathrm{F}=146.004$; p < 0.05) (Freedman, 2005; Krushkal \& Tanur, 1978; Leech, 2005; Lindley, 1987). Table 5 showed the standardized Beta Coefficients that present the contributions of each variable to the model. The $t$ and $p$ values showed the impact of the independent variables on the dependent variable (Freedman, 2005; Krushkal et al., 1978; Leech, 2005; Lindley, 1987). From Table 5, it was clear that the construct Observability had the highest impact on attitude (the dependent variable, while Trialability has the least impact on attitude. The large $t$ value and corresponding low $p$ value buttressed the result for Observability which had the highest Beta coefficient (both standardized and unstandardized).

The multiple regression equation for this analysis consequently was:

Attitude $=0.111+0.252($ Relative Advantage $)+0.152$ (Complexity $)+0.231$ (Compatibility $)+$ 0.077(Trialability) +0.294 (Observability). 
Tables 6, 7 and 8 present the results from the multiple regression carried out using Attitude as the independent variable and Intention as the dependent variable. This was done to determine the best linear combination of attitude for predicting Intention.

Table 6: Model Summary for attitude and intent

\begin{tabular}{l|llll}
\hline Model & $\mathbf{R}$ & R Square & Adjusted R S quare & $\begin{array}{l}\text { Std. Error of the } \\
\text { Estimate }\end{array}$ \\
\hline 1 & $.712(\mathrm{a})$ & .507 & .506 & .509 \\
\hline
\end{tabular}

Table 7: ANOVA for attitude and intent

\begin{tabular}{|c|c|c|c|c|c|c|}
\hline Model & & $\begin{array}{l}\text { Sum of } \\
\text { Squares }\end{array}$ & Df & $\begin{array}{l}\text { Mean } \\
\text { Square }\end{array}$ & $\mathbf{F}$ & Sig. \\
\hline \multirow[t]{3}{*}{$\mathbf{1}$} & Regression & 106.417 & 1 & 106.417 & 410.115 & $.000(a)$ \\
\hline & Residual & 103.533 & 399 & .259 & & \\
\hline & Total & 209.950 & 400 & & & \\
\hline
\end{tabular}

Predictors: (Constant), Attitude

Dependent Variable: Intent

Table 8: Coefficients for attitude and intent

\begin{tabular}{l|l|lllllll}
\hline \multicolumn{2}{l|}{ Model } & $\begin{array}{l}\text { Unstandardized } \\
\text { Coefficients }\end{array}$ & $\begin{array}{l}\text { Standardized } \\
\text { Coefficients }\end{array}$ & & \multicolumn{3}{c}{$\begin{array}{l}\text { Collinearity Statis- } \\
\text { tics }\end{array}$} \\
\hline 1 & & B & $\begin{array}{l}\text { Std. } \\
\text { Error }\end{array}$ & Beta & T & Sig. & Tolerance & VIF \\
& & & & & & & & \\
& (Constant) & 1.025 & .155 & & 6.632 & .000 & & \\
& Attitud & .804 & .040 & 0.712 & 20.251 & .000 & 1.000 & 1.000 \\
\hline
\end{tabular}

Dependent Variable: Intent

From Table 6, it can be seen that the R Square value for the model showed that $50.6 \%$ of the variance in the model can be predicted from the independent variable, attitude. Table 7 gives the ANOVA test on the general significance of the model. As $\mathrm{p}$ is less than 0.05 , the model is significant. Thus, attitude significantly predicted the dependent variable Intention $(\mathrm{F}=410.115 ; \mathrm{p}<$ 0.05). Table 8 showed the standardized Beta Coefficient. A unit change in the independent variable Attitude would produce an effect on the dependent variable, Intention. From this table, Attitude had a high impact on Intention The large $t$ value and corresponding low $p$ value supports the result for which there is a high Beta coefficient. In this regression, the $\mathrm{R}$ square value is 0.506. 1$\mathrm{R}^{2}$ gives 0.494 and thus there is not likely to be the problem of multicollinearity between Attitude and Intention. VIF gives the same information as tolerance.

The multiple regression equation for this analysis consequently is:

Intention $=1.025+0.804$ (Attitude)

\section{Test of Hypotheses}

Table 9 showed the results of the hypothesis tested against the $\mathrm{p}$ values that were obtained from the results above. These values were shown summarily below. 
Table 9: Summary of Values for the constructs

\begin{tabular}{lll}
\hline Variables & Beta & $\boldsymbol{P}$ \\
\hline Relative Advantage & 0.231 & $\mathrm{P}<0.05$ \\
Complexity & 0.164 & $\mathrm{P}<0.05$ \\
Compatibility & 0.232 & $\mathrm{P}<0.05$ \\
Observability & 0.318 & $\mathrm{P}<0.05$ \\
Trialability & 0.090 & $\mathrm{P}<0.05$ \\
\hline
\end{tabular}

Relative Advantage $(\beta=0.231, \mathrm{p}<0.05)$ was found to have a significant positive effect on the attitude towards using ATM. From the responses, the advantages of using ATMs have made them prefer ATM use than the traditional transactions with bank tellers. Some of these advantages include speed, efficiency, availability, ease of use, faith in the security of their personal information concerning ATM use (such as pin numbers) etc. The significant contribution of Relative Advantage to the Diffusion of Innovation (DOI) model is consistent with previous research involving information system acceptance (Horton et al., 2001; Morris \& Dillon, 1997).

The contribution of the Complexity construct $(\beta=0.164, \mathrm{p}<0.05)$ was positively significant to the model and hence supported in this study. The complexity of a technology affects how well that technology diffuses in a social system because if the technology is easy to use, more people are likely to adopt its use (Rogers, 1995). Findings from this study suggested that ATMs were quite easy to use and more likely to be more widely adopted. However, Complexity contributed less than Relative Advantage and Compatibility to the DOI model. Its contribution though, was markedly more than that of the Trialability construct. The significant contribution of Complexity to the diffusion model was supported by previous studies such as Kolodinsky et al. (2004), Chen et al. (2002), Lau (2002) and Taylor and Todd (1995).

The Compatibility construct $(\beta=0.232, \mathrm{p}<0.05)$ was found to positively contribute to the DOI model. The influence of its contribution was found to be almost the same as that of Relative Advantage with $\beta=0.231$ and $p<0.05$. This suggested that the compatibility of ATM usage to the lifestyle of the respondents was important. Compatibility contributed similarly as Relative Advantage regarding the fostering of a positive attitude towards adopting the use of ATMs possibly because indeed it was a great advantage in itself. The use ATMs now belong firmly in the "modern" way of doing things. The significant contribution of Compatibility to the DOI model was also highlighted in other studies particularly those of Chen et al. (2002) and Tan and Teo (2000).

Notably, the Observability construct $(\beta=0.318), p<0.05)$ had the highest impact on the attitude towards the use of ATM. This could be because ATM is usually found in public places. It also showed that people paid more attention to it than might have previously been the case. The Observability construct was not simply about watching others using the technology, but (as the results from the factor analysis revealed) involved perception and discernment, usually brought on by the influence of others ( in this case, other ATM users probably known to potential and new adopters). Other studies have shown the contribution of Observability to the DOI model (Tan and Teo, 2000; Taylor \& Todd, 1995).

Of the five constructs, Trialability $(\beta=0.090, \mathrm{p}<0.05)$ had the least impact on the attitude towards using ATMs, although it was positively signif icant. The results implied that the respondents have attempted to try ATMs before adopting its use. This finding on the other hand suggested that people just decide to adopt and use ATM without first testing it for a while. This could be because of their already perceived notions as to the advantages of using ATMs. Still, since the construct was significant in this study, it meant that potential adopters of ATM may well benefit 
from trial demonstrations as an introduction to us ing the technology. This would help eliminate uncertainty about ATMs, improve confidence in its use and make its diffusion more widespread (as in Nigeria where there are still areas without ATMs). The Attitude $(\beta=0.712, p<0.05)$ towards ATMs positively and significantly affected the Intention to use the technology. The high impact of Attitude on Intention to use ATMs expressed the importance of how Attitude could affect the Intention to use an ATM. A positive attitude meant that a potential adopter or a past user of an ATM would have the Intention to use it in future and vice versa. The contribution of Attitude to Intention in the DOI model has been in line with the findings of other studies such as those of Chang and Cheung, (2001) and Davis et al (1989).

These findings have shown what the Diffusion of Innovation model portends in the diffusion of ATMs. It is therefore noteworthy for banks examine the attributes of the model in the light of their local situations to see how they could improve on their deployment of ATMs and customers' satisfaction with ATM service(s). If more people are gratified by their use of ATMs, the customer base of banks is likely to increase, subsequently improving the prof it margins.

The results are summarized in Table 10 and Figure 2.

\section{Table 10: Hypotheses Results}

\footnotetext{
H1 The Relative advantage of using Automatic Teller Machines does not positively affect Rejected the attitude towards using the technology.
}

H2 The Complexity of the use of Automatic Teller Machines does not positively affect the Rejected attitude towards using the technology.

H3 The Compatibility of Automatic Teller Machines with the adopter's values does not Rejected positively affect the attitude towards using the technology.

H4 The Trialability of Automatic Teller Machines does not positively affect the attitude Rejected towards using the technology.

H5 The Observability of Automatic Teller Machines does not positively affect the attitude Rejected towards using the technology.

H6 The Attitude towards Automatic Teller Machines does not positively affect the inten- Rejected tion to use the technology. 


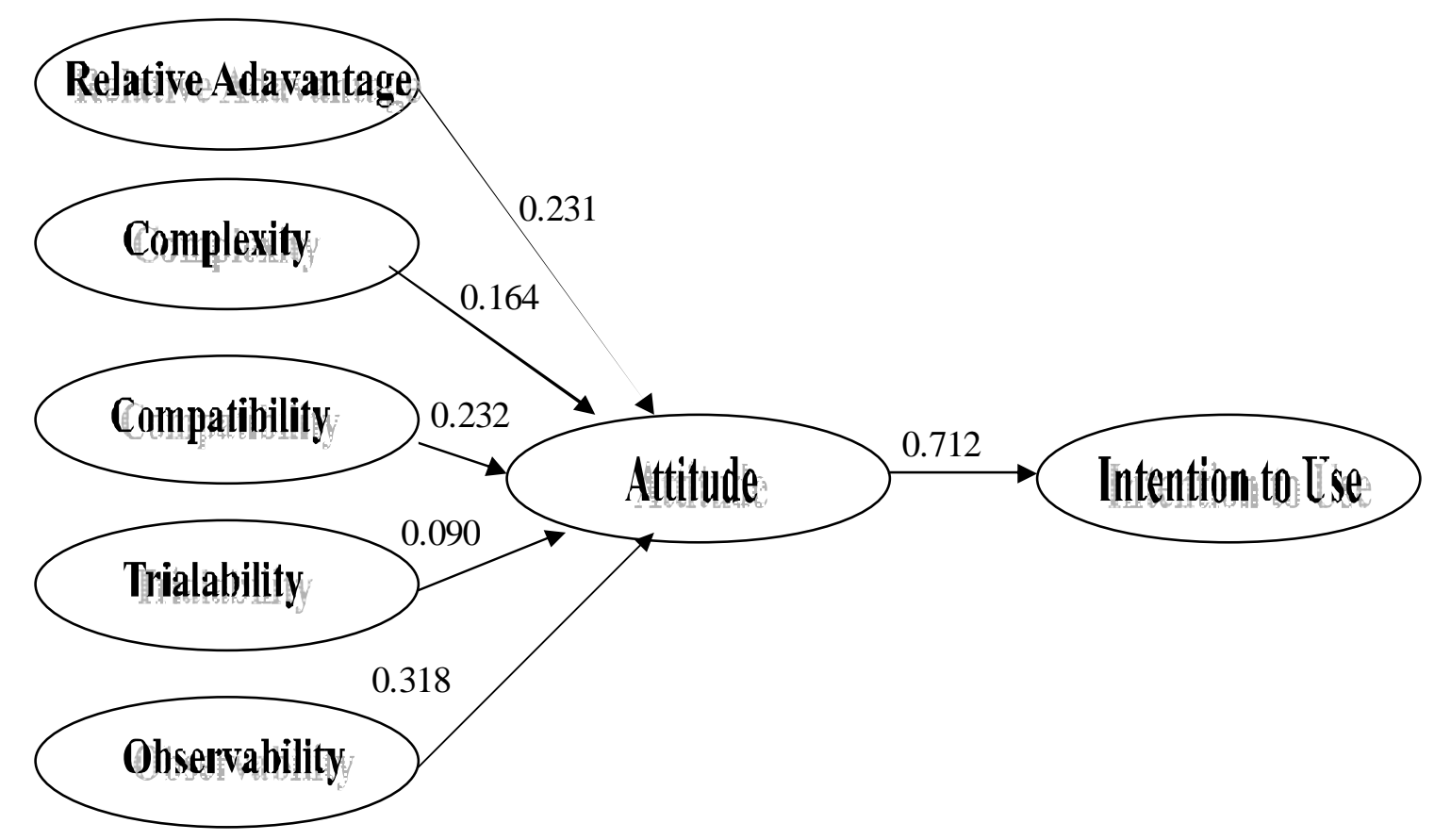

Figure 2: Findings on the DOI constructs

\section{Discussion}

The findings showed that attitudinal dispositions significantly influence use of ATM. All the five attitudinal constructs have strong influences on adoption and intention to use ATM. From the Factor Analysis for the Relative Advantage construct, it was evident that the respondents believed that the information concerning the ir use of ATMs was secure, and their using ATM was safe. This supported Sheth's (1981) proposition that lowered perceived risk increases the likelihood of consumer adoption. Also, the use of ATMs appeared to be convenient compared with using the teller in the banking hall. Complexity also has signif icant relationship with intention to use ATM. This result corroborates the findings of Cheung et al. (2000). Findings in relation to the complexity construct revealed that ATMs were quite simple to use, and were efficient (at least relative to transacting with a human cashier). According to Rogers (1995) the harder an innovation is to use, or perceived to use, the less likely that an adopter would use it. Therefore, as ATMs seemed to be easy to use, it means their use would be more widely adopted in the nearest future. This finding suggests that easy to use technologies should be put in place by banks in order to enhance usage. Compatibility is another factor that influences attitude and intention to use ATM. Given that individuals have already established personal banking norms, lifestyle, finance management system, and account monitoring mechanism prior to the advent of ATM, their acceptance or rejection of the technology will rely greatly on the extent to which it accommodates or rejects all or some of these past values. Previous studies have shown that some people have phobia for change, and will avoid change if they can. This might explain why more compatible ATM would be needed to be adopted by banks. Analys is for compatibility revealed that the use of ATM was compatible with the lifestyle of the respondents. It was also revealed that ATM's use is widespread today because of its usefulness but because of its compatibility with users' previous values and its being a current practice. This supports previous studies that modern systems accept and adapt to innovation faster and easier than traditional systems (Blackwell et al., 1995). Hence, there was the possibility that there were those who would use ATM to be part of the trend.

In addition, the impression that there was privacy while using an ATM was not very strong, probably because ATMs were situated in public places (such as outside banking halls), and most 
ATMs were not enclosed in such a way that the user was alone with the ATM while transacting. Sometimes, there were long queues, or two or three people crowding close to someone using an ATM. This finding suggests that there was a need for privacy to be included in the provis ion of better ATM services by banks. This could also help in boosting security of private information concerning ATM use, such as pin numbers. In addition, it was not strongly felt that all the transactions with ATMs were all good experiences, which meant that at one time or the other, an adopter might experience a fault with the use of an ATM. It was not strongly felt that withdrawing from an ATM was less safe than withdrawing from a bank teller. This was probably due to the fact that after withdrawal of money, whether from an ATM or bank teller, it was possible for crime to be committed against the user after he/she had left the scene. This did not appear to stop the respondents from believing in the security of the ir ATM information such as pin numbers, passwords, etc, which is a strong reason why ATMs are patronized today.

Findings on the Observability construct showed that the observations made by the respondents effectively convinced them to use ATMs which corroborate the theoretical underpinnings of the social learning theory that people learn from others by observing them (Rogers, 2003). Influence was apparently a factor for using ATM probably because users are likely to encourage others to do the same (Weiss, 1969; Shao, 2007). Another construct that influenced attitude supported in this study is trialability. Thus, potential ATM adopters will be more inclined to use it if they can try it out first. The Trialability construct only loaded into one factor. It showed that ATMs were tested or tried out usually before steady usage. Trying out ATM before conscious adoption and eventual use was more likely to inspire confidence in using it. This was significant because ATMs were located in public places, and a user might not want to appear in public as a novice while using it. Studies have shown that most people will not adopt an innovation without first personally testing it to see if it could fit into the ir needs and desires (Rogers, 1995).

\section{Conclusions, Implications and Future Studies}

This study has been revealing concerning the issues surrounding the adoption of ATMs - especially from the perspective of the adopters. Rogers (1995) Diffusion of Innovation Theory (DOI) was applied in this study particularly to discover how the interplay of the five major constructs: Relative Advantage, Complexity, Compatibility, Observability and Trialability would impact on the attitude regarding ATM and furthermore, to determine how attitude would impact on the Intention to use ATMs. From the results, it could definitively be said that the Relative Advantage of using ATMs; how hard it was to use ATMs, how compatible ATMs were with the lifestyle of the users; how much has been registered (observed) about ATMs by the users and whether ATMs could be tested before consistent use, were issues that influence users' attitude towards intention to use ATMs. The Attitude of an ATM user would later affect his/her intent to use an ATM. Since Observability had the greatest impact on attitude, it is important for banks to give the right impression about ATMs. This could be in terms of locating ATMs in hidden places so that nonadopters could observe others use ATM before adopting it themselves. Specifically, the following strategies would assist in consummating greater diffusion of ATM in Nigeria: enhanced salience of ATM to customers' needs, greater compatibility of ATM to customers banking norms and lifestyle, less complex and easy to use system that does not require a lot of mental and physical efforts to accomplish transactions (easy to read, comprehensive information or instructions on the system, prompt processing of transactions, interactivity, etc) and opportunity for adopters to experiment with the system before making any long-term commitment (Ndubisi \& Sinti, 2006).

Future studies might include more locations to discover if there were any specifics on diffusion particular to geographical location and the cultural considerations of an area. Other models and theories on diffusion could be used in conjunction with Roger's (1995) theory on diffusion to discover more about the diffusion of ATMs in Nigeria. The diffusion of ATM in Nigeria could also 
be studied from the perspective of non-users to determine why they persist in not using it. It could also be studied from the perspective of adoption factors by banks, looking into why some banks would not deploy ATMs, or if they have deployed ATMs, what could limit or enhance it.

\section{References}

Agboola, A. (2006). Information and communication technology(ICT) in banking operations in Nigeria: An evaluation of recent experiences. Retrieved December 25, 2007, from http://unpan1.un.org/intradoc/groups/public/documents/AAPAM/UNPAN026533.pdf

Amel, D. F. (1986). Consumer use of automated teller machines. Working papers in Banking, Finance, \& Microeconomics, No. 86-5, Financial Structure Section, Division of Research and Statistics, Board of Governors of the Federal Reserve System.

Batiz-Lazo, B., \& Barrie, A. (2005). The business and technological history of automated teller machines in the UK, 1967-2005, a Primer. Conference Abstracts, 16-17th June. Queen Mary, University of London.

Blackwell, R. D., Engle, J. F., \& Miniard, P. W. (1995). Diffusion of innovations in consumer behavior. London: Dryden Press.

Chang, M. K., \& Cheung, W. (2001). Determinants of the intention to use Internet/www at work: A confirmatory study. Information and Management, 39(1), 1-14.

Chen, L., Gillenson, M. I., \& Sherrell, D. L. (2002). Enticing online consumers: An extended technology acceptance perspective. Information \& Management, 39(8), 705 - 719.

Darch, U., \& Caltabiano, N. J. (2004). Investigation of automatic teller machine banking in a sample of older adults. Australasian Journal on Ageing, 23(2), 100-103.

Davis, F. D., Bagozzi, R. P., \& Warshaw, P. R. (1989). User acceptance of computer technology: A comparison of two theoretical models. Management Science, 35(8), 982-1003.

Di Angeli, A., Coventry, L., \& Johnson, G. I. (2002). ATM's adoption in developing countries: Déjà vu or not? Advanced Technology and Research, Dundee, UK: NCR Financial Solutions Division.

El-Haddan, A., \& Almahmeed, M. (1992). ATM banking behaviour in Kuwait: A consumer survey. International Journal of Bank Marketing, 10(3), 250-232.

Fanawopo, S. (2006). World without cash-Nigeria's payment card grows significantly. Retrieved October 15, 2007, fro $\mathrm{m}$ http://www.sunnesws online.com

Fasan, R. (2007). Ban ks, customer relation and use of ATM cards. Business Day Newspapers. Retrieved February 28, 2008, from $\mathrm{http}: / / \mathrm{ww} w$. business dayonline.com/

Fishbein, M., \& Ajzen, I. (1975). Belief, attitude, intention and behavior: An introduction to theory and research. Reading, MA: Addison-Wesley.

Frame, S. W., \& White, L. J. (2002). Empirical studies of financial innovation: Lots of talk, little action? Federal Reserve Bank of Atlanta Working Paper No. 2002-22. Atlanta, USA.

Freed man, D. A. (2005). Statistical models: Theory and practice. UK: Camb ridge University Press.

Gerrard, P., \& Cunningham, J. B. (2003). The diffusion of internet banking among Singapore consumers. International Journal of Bank Marketing, 21(1), 16-28.

Hardgrave, B. C., Davis, F. D., \& Rie menschneider, C. K. (2003). Investigating determinants of software developers' intentions to follow methodologies. Journal of Management Information Systems, 20(1), 123-151.

Hone, K. S., Graham, R., Maguire, M. C., Baber, C., \& Johnson, G. I. (1998). Speech technology for automatic teller machines: An investigation of user attitude and performance. Ergonomics, 41(7) 962-981. 
Horton, R. P., Buck, T., Waterson, P. E., \& Clegg, C. W. (2001). Exp laining intranet use with the technology acceptance model. Journal of Information Technology, 16(4), 237-249.

Intermarc Consulting Limited. (2007). Nigeria e-banking customer survey on cards, ATM and PoS. Retrieved October 12, 2008, from http://www.thenationonlineng.com/dynamicpage.asp?id=36290

Karahanna, E., Straub, D. W., \& Chervany, N. L. (1999). Information technology adoption across time: A cross-sectional comparis on of pre-adoption and post-adoption beliefs. MIS Quarterly, 23(2), 183-213.

Kennickell, A. B., \& Kwast, M. L. (1997). Who uses electronic banking? Results from the 1995 survey of consumer finances. Presented at the Annual Meeting of the Western Economic Association, July, Seattle, Washington.

Kolodinsky, J. M., Hogarth, J. M., \& Hilgert, M. A. (2004). The adoption of electronic banking technologies by US consumers. International Journal of Bank Marketing, 22(4/5), 238- 259.

Kruskal, W. H., \& Tanur, J. M. (1978). Linear hypotheses. International Encyclopedia of Statistics. 1, Free Press.

Laderman, E. S. (1990). The public policy implications of state laws pertaining to automated teller machines. Federal Reserve Bank of San Francisco Economic Review, 1, 43-58.

Lau, S. M. (2002). Strategies to motivate brokers adopting on-line trading in Hong Kong financial market. Review of Pacific Basin Financial Markets and Policies, 5(4), 471,-489.

Lee, E. \& Lee, J. (2000). Haven't adopted electronic financial services yet? The acceptance and diffusion of electronic banking technologies. Financial Counselling and Planning, 11(1), 49-60.

Leech, N., Barrett, K., \& Morgan, G., A. (2005). SPSS for intermediate statistics: Use and interpretation (2nd ed.). London: Lawrence Erlbaum Associates.

Lindley, D. V. (1987). Regression and correlation analysis. A Dictionary of Economics, 4, 120-23. R New Palgrave: Macmillan Publishing Company.

Marshall, J., \& Heslop, L. (1988). Technology acceptance in Canadian retail banking. International Journal of Bank Marketing, 6(4), 31-41.

McAndrews, J. J. (2003). Automated teller mach ine network pricing - A review of the literature. Review of Network Economics, Federal Reserve Bank of New York. 2(2) New York, USA.

Merton, R. C. (1992). Financial innovation and economic performance. Journal of Applied Corporate Finance, 4 (Winter), 12-22.

Moore, N. (1987). How to do research. London: Wiltshire.

Moore, G. C., \& Benbasat, I. (1991). Develop ment of an instrument to measure the perceptions of adopting an information technology innovation. Information Systems Research, 2(3), 192-222.

Morris, M. G., \& Dillon, A. (1997). How user perceptions influence software use. IEEE Software, 14(4), 58-65.

Mustonen-Ollila, E., \& Lyytinen, K. (2003). Why organizations adopt information system process innovations: A longitudinal study using diffusion of innovation theory. Information Systems Journal, 13(3), 275-297.

Ndubisi, N. O., \& Sinti, Q. (2006). Consumer attitudes, system's characteristics and internet banking adoption in Malaysia. Management Research News, 29(1/2), 16-27.

Omankhanlen, O. (2007). ATM: Rising threats and users' dilemma. Retrieved January 16 2008, from http://www.tribune.com.ng

Osiki, J. O. (2006). Use of a research questionnaire. In A. I. Olay inka, V. O. Taiwo, A. Raji-Oyelade, \& I. P. Farai (Eds.), Method of basic and applied research (2nd ed.). The Post Graduate School, University of Ibadan. 
Parthasarathy, M., \& Bhattacherjee, A. (1998). Understanding post-adoption behavior in the context of online services. Information Systems Research, 9(4), 362-379.

Pennings, J. M., \& Harianto, F. (2007). The diffusion of technological innovation in the commercial banking industry. Strategic Management Joumal, 13(1), 29-46.

Plouffe, C. R., Hulland, J. S., \& Vandenbosch, M. (2001). Research report: Richness versus parsimony in modeling technology adoption decisions - Understanding merchant adoption of a smart card-based payment system. Information Systems Research, 12(2), 208-222.

Rogers, E. M. (1995). Diffusion of innovations (4th ed.). The Free Press: New York.

Rogers, E. M. (2003). Diffusion of innovations (5th ed.). The Free Press: New York.

Rogers, A., Fisk, A. D., Mead, S. E., Neff, W., \& Cabrera, E. F. (1996). Training older adults to use automatic teller machines. Human Factors, 38. Retrieved October 182008 from http://www.questia.com

Rugimbana, R. (1995). Predicting automated teller machine usage: The relative importance of perceptual and demographic factors. International Joumal of Bank Marketing, 13(4), 26-32.

Shao G. (2007). The diffusion of online banking: Research trends from 1998 to 2006. Journal of Internet Banking and Commerce, 12(2), 1-13.

Sheth, J. N. (1981). Psychology of innovation resistance: The less developed concept (LDC) in diffusion research. Research in Marketing, 4, 273-282.

Swinyard, W. R., \& Ghee, L. (1987). Adoption patterns of new banking technology in Southeast Asia. International Journal of Bank Marketing, 5(4), 35-48.

Tan, M., \& Teo, T. S. H. (2000). Factors influencing the adoption of internet banking. Journal of the Association for Information Systems, 1(1) 1-42.

Taube, P. M. (1988). The influence of selected factors on the frequency of ATM usage. Journal of Retail Banking, 10(1), 47-52.

Taylor, S., \& Todd, P. (1995). Understanding information technology usage: A Test of Competing Models. Information Systems Research, 6(2) 144-176.

Tornatzky, L. G., \& Fleischer, M. (1990). The process oftechnological innovation. New York: Pergamon Press.

Ugwu, E. (2008). CBN, banks to tackle ATMs' hitches. Retrieved April 18, 2008, from http://www.guardiannewsngr.com

Venkatesh, V., Morris, M. G., Davis, G. B., \& Davis, E. D. (2003). User acceptance of information technology: Towards a unified view. MIS Quarterly, 27(3) 425-478.

Weiss. (1969). The role of interpersonal communication. In effects of the mas media of communication, In Lindzey \& Aronson, Handbook of Social Psychology. 5, 141-177. 


\section{Biographies}

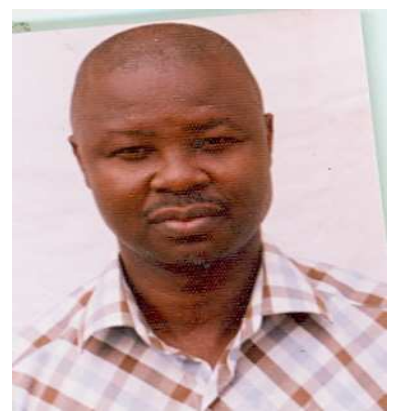

Dr. Wole Michael Olatokun obtained his Master and $\mathrm{PhD}$ degrees in Information Sc ience from Africa Regional Centre for Information Science (ARCIS), the University of Ibadan, Nigeria. He is currently a Senior Lecturer at the Department of Library and Information Studies, University of Botswana, Gaborone. His research interests include: National Information and Communication Technology (ICT) policy issues, Social informatics, Gender and ICT, eCommerce, eGovernment and Mobile Commerce, ICT adoption and application in different settings, and indigenous knowledge systems. He can be contacted by email at:

wole.olatokun@mopipi.ub.bw/woleabbeyolatokun@yahoo.co.uk

Louisa Joyce Igbinedion holds degree of Master of Information Science obtained from Africa Regional Centre for Information Science (ARCIS), University of Ibadan, Nigeria. Her research interests include: Gender and Technology, Behaviour and technology adoption, Ethical and policy issues in information systems and Issues in information science research. She can be contacted at eagleviewng@yahoo.com 